\title{
Albanian Literature in Its Critical Evaluation Process. Case Study: Periodicals
}

\author{
MARISA KËRBIZI \\ EDLIRA MACAJ
}

\begin{abstract}
The aim of this article is to analyze the process of evaluation of Albanian literature in literary periodicals (print or online). The research aims to explain the nature of criticism of Albanian literature in accordance with three main periods of Albanian literary history (1920-1944; 1945-1990; 1991-present). The paper has a short chronological presentation of the main periodicals which deal with literature. It also deals with the reception of Albanian literature in old and new periodicals. Some of the most important research questions of this paper are: Is there a continuation in the critical approaches to Albanian literature from the beginning to the present? Do critics have a 'critical' interaction between them while they express their evaluation regarding literature? Who are the critics? Which is the core role of certain critics and periodicals? The methodology used in this paper embraces a historical, analytical, statistical and interpretative approach. The paper will be developed in two parallel sections. The first one will elaborate quantitatively official data related to the number of periodicals which deal with the evaluation of literature in its theoretical and critical aspects and the other section will describe, analyze and interpret the data. The research results tend to prove that the process of critical evaluation of Albanian literature has experienced similar characteristics with Albanian literature itself. The critical reflection or criticism has turned out to be a refracting process. The critical evaluations are marred occasionally by low levels of professionalism or political interference.
\end{abstract}

Keywords: Albanian literature; criticism; evaluation; periodical; flexibility; statistics

\section{7-1945: Paradigm of Constructive Debate in Albanian Literary Criticism}

Literary studies in Albania had their beginnings with the impressions and journalistic reviews that were occasionally published in the Albanian journal of Faik Konica, which was published on March 25th 1897 in Brussels. The constructive debate in Albanian literary criticism was initiated in this journal, which is even today considered to be one of the most important events ever in 
Albanian literary studies. (Visoka 2012: 28) This periodical remains one of the most important milestones in Albanian literary criticism.

The period of time between the two world wars was very dynamic. Albanian literature entered a new stage in its development and reached its peak. Writers such as Koliqi, Kuteli, Poradeci, Pipa, etc., had all graduated from European universities and they brought their best practices to Albania.

Some of them were not only writers but also the first literary critics as well. The first periodicals were published because of their good evaluation competence. They paved a way to Albanian literary criticism through constructive debate and helped in the consolidation of diversity in Albanian literary studies. It is due to their initiative in publishing the first interdisciplinary journals and periodicals; in some periodicals, literary studies had the principal function and in some others they had only a peripheral role. However, there were some literary periodicals like Zana (The Fairy), first published in 1914, Kopshti letrar (The Literary Garden), published in 1918-1919, or Agimi (The Dawn) published in 1919, ABC (1937), Kritika (Criticism) published in 1944, etc., that had an entirely literary focus.

The researcher Dhurata Shehri states that the main role of critical studies in this period was to emancipate the readers. The outstanding reviews of Faik Konica, Mitrush Kuteli, Krist Maloki, Arshi Pipa, Vangjel Koça, etc., are a clear evidence of this tendency. (Shehri 2012: 146) Literary periodicals were first published in some of the most important cities of Albania, like Shkodra, Tirana, Korca, etc.

Ernest Koliqi (1903-1975), writer and researcher, has provided a panoramic overview of the transformation of Albanian literature in the 1930s. He expressed his own viewpoint related to the emerging writers and literary critics, for whom he had reservations. He estimated highly traditional writers like Naim Frasheri, Gjergj Fishta, etc.

He also took under consideration the quality of Albanian periodicals. Koliqi divided them into two main categories; the high standard periodicals like Hylli $i$ Dritës (The Star of Light) and LEKA and the medium ones like Cirka (The Spot) and Kumbona e së diellës (The Sunday Bell). The journals of the second category were published by private funds (Koliqi 2003: 156-158) and they sometimes lacked financial stability.

Journals with informative and literary content were mostly published by Albanian intellectuals who had graduated from European universities. Some of the most important periodicals were published simultaneously in Albanian, English and French, for example Përpjekja shqiptare (Albanian Endeavour) published in 1937 a special edition, No. 9-10 in Albanian and French. This special edition was an tribute paid to Rene Descartes. Biblioteka, Zëri i Shqipërisë (The Library the Voice of Albania) was another Albanian literary 
KËRBIZI, MACAJ

journal, published by Themistokli Germenji on March 28 1919. It was a literary and political journal published in Albanian, English and French.

1900-1925 were the years when local publications blossomed. It is important to stress that one of the periodicals Ylli i mëngjesit (The Morning Star) was published by the teacher Parashqevi Qiriazi (1917-1920). This is very important in understanding the development of a new intellectual generation, with the contribution of women intellectuals as well.

After the Second World War, the totalitarian communist regime was established in Albania and after that most of the periodicals were not published any longer. For example, the journal Criticism, established by Arshi Pipa in 1944, had just started a new mission of evaluating the tradition of Albanian Literature. This mission was interrupted because Arshi Pipa was arrested and then imprisoned for ten years. A similar misfortune awaited publishers, writers and other intellectuals. Ernest Koliqi and Martin Camaj escaped from Albania; Mitrush Kuteli, Musine Kokalari were arrested; Father Anton Arapi (writer and priest) and Vincens Prendushi were executed, etc.

Table 1. Periodicals published until 1944

\begin{tabular}{|c|c|c|c|}
\hline $\begin{array}{c}\text { Year of } \\
\text { Publication }\end{array}$ & Title & Main Features & $\begin{array}{c}\text { Place of } \\
\text { Publication }\end{array}$ \\
\hline 1897 & Albania & Cultural, literary & Brussels, Belgium \\
\hline 1897 & L'Albania letteraria & $\begin{array}{l}\text { Cultural, literary } \\
\text { journal published } \\
\text { in Italian }\end{array}$ & $\begin{array}{l}\text { Corigliano Calabro, } \\
\text { Italy }\end{array}$ \\
\hline 1901-1909 & $\begin{array}{l}\text { Drita } \\
\text { (The Light) }\end{array}$ & \begin{tabular}{|l|} 
Interdisciplinary \\
journal
\end{tabular} & Sofia,Bulgaria \\
\hline 1909-1929 & $\begin{array}{l}\text { Diturija } \\
\text { (The Knowledge) }\end{array}$ & $\begin{array}{l}\text { Cultural and } \\
\text { literary journal }\end{array}$ & $\begin{array}{l}\text { Thessaloniki } \\
\text { (Greece) Bucharest } \\
\text { (Romania), Tiranë } \\
\text { (Albania) }\end{array}$ \\
\hline 1909-1992 & $\begin{array}{l}\text { Dielli } \\
\text { (The Sun) }\end{array}$ & $\begin{array}{l}\text { Informative, literary } \\
\text { journal }\end{array}$ & Boston, USA \\
\hline $\begin{array}{l}1910-1911 \\
1913-1915 \\
1915-\end{array}$ & $\begin{array}{l}\text { Koha (The Time) / } \\
\text { Bashkimi (The Union) /* } \\
\text { Besa shqyptare } \\
\text { (Albanian Word of Honour) / } \\
\text { Zani i Shkodrës } \\
\text { (The Voice of Shkodra) }\end{array}$ & $\begin{array}{l}\text { Informative, } \\
\text { cultural, literary } \\
\text { journal }\end{array}$ & Shkodër, Albania \\
\hline $1912-1927$ & $\begin{array}{l}\text { Kalendari i vjetës } \\
\text { (The Annual Calendar) }\end{array}$ & $\begin{array}{l}\text { Cultural, literary, } \\
\text { historical, religious } \\
\text { journal }\end{array}$ & Shkodër, Albania \\
\hline
\end{tabular}


Albanian Literature in Its Critical Evaluation Process.

\begin{tabular}{|c|c|c|c|}
\hline $\begin{array}{c}\text { Year of } \\
\text { Publication }\end{array}$ & Title & Main Features & $\begin{array}{c}\text { Place of } \\
\text { Publication }\end{array}$ \\
\hline 1912 & $\begin{array}{l}\text { Fjala e tim zoti } \\
\text { (Word of my Lord) }\end{array}$ & $\begin{array}{l}\text { Cultural, religious } \\
\text { journal }\end{array}$ & $\begin{array}{l}\text { Hora of Arbëresh, } \\
\text { Italy }\end{array}$ \\
\hline 1913-1944 & $\begin{array}{l}\text { Hylli i dritës } \\
\text { (The Star of Light) }\end{array}$ & $\begin{array}{l}\text { Informative, literary } \\
\text { journal published in } \\
\text { Albanian, French, } \\
\text { Italian, German, } \\
\text { English }\end{array}$ & Shkodër, Albania \\
\hline 1913 & LEKA & Cultural, literary & Shkodër, Albania \\
\hline 1914 & Zana (The Fairy) & Literary & Durrës, Albania \\
\hline 1916 & Përparimi (The Progress) & Cultural & New York, USA \\
\hline 1917-1920 & $\begin{array}{l}\text { Ylli i mëngjesit } \\
\text { (The Morning Star) }\end{array}$ & $\begin{array}{l}\text { Pedagogical, } \\
\text { cultural journal }\end{array}$ & Boston, USA \\
\hline 1918-1919 & $\begin{array}{l}\text { Kopshti letrar } \\
\text { (The Literary Garden) }\end{array}$ & Literary journal & Elbasan, Albania \\
\hline 1919 & Agimi (The Dawn) & Literary journal & Shkodër, Albania \\
\hline 1919 & Ylliria & $\begin{array}{l}\text { Political, literary } \\
\text { journal. }\end{array}$ & Tiranë, Albania \\
\hline 1919 & \begin{tabular}{|l|} 
Biblioteka, \\
Zëri i Shqipërisë \\
(The Library, Voice of Albania)
\end{tabular} & $\begin{array}{l}\text { Political and } \\
\text { literary journal }\end{array}$ & Sofia, Bulgaria \\
\hline $1921-1930$ & $\begin{array}{l}\text { Posta e Korçës } \\
\text { (The Post Office of Korça) }\end{array}$ & Literary Suplement & Korçë, Albania \\
\hline $1921-1923$ & Shkëndija (The Spark) & Cultural, literary & Korçë, Albania \\
\hline 1929 & $\begin{array}{l}\text { Studenti shqiptar } \\
\text { (The Albanian Student) }\end{array}$ & Cultural & Torino, Italy \\
\hline 1929-1937 & Arbëria & $\begin{array}{l}\text { Political, } \\
\text { economical, } \\
\text { cultural, literary } \\
\end{array}$ & Tiranë, Albania \\
\hline 1930 & Ars & Informative, literary & Korçë, Albania \\
\hline $1932-1936$ & Minerva & $\begin{array}{l}\text { Scientific literary } \\
\text { journal }\end{array}$ & Tiranë, Albania \\
\hline 1934-1936 & $\begin{array}{l}\text { Rilindja } \\
\text { (The Reinassance) }\end{array}$ & $\begin{array}{l}\text { Social, cultural, } \\
\text { literary journal }\end{array}$ & Korçë, Albania \\
\hline 1936-1939 & $\begin{array}{l}\text { Përpjekja shqiptare } \\
\text { (Albanian Endeavour) }\end{array}$ & $\begin{array}{l}\text { Cultural, social, } \\
\text { philosophical, } \\
\text { economical, } \\
\text { literary journal }\end{array}$ & Tiranë, Albania \\
\hline 1940-1943 & Shkëndija (The Spark) & $\begin{array}{l}\text { Cultural, literary } \\
\text { journal }\end{array}$ & Shkodër, Albania \\
\hline 1944 & Fryma (The Spirit) & $\begin{array}{l}\text { Literature and } \\
\text { critical studies }\end{array}$ & Tiranë, Albania \\
\hline 1944 & Kritika (Criticism) & Literary journal & Tiranë, Albania \\
\hline
\end{tabular}


KËRBIZI, MACAJ

\section{5-1990: Paradigm of Ideological Criticism}

The period between 1945 and 1990 is completely different from the first. For the first time in the history of Albanian journalism, all the private and independent newspapers and journals were suspended (Fevziu 2005: 79). Literary journals and literary studies published in this period were deeply influenced by the communist ideology. As a result, literary criticism was unable to produce a real evaluation of the literary process. Moreover, even literature suffered from the consequences of the application of social realism, the absence of freedom, etc. Literature was censored and as a result it changed its natural developing process. Many writers were condemned, imprisoned and even executed. (Kërbizi \& Macaj 2019: 126). According to Dhurata Shehri, after 1945 Albanian literature abruptly stopped communications with the literature written by Albanian writers published in Kosovo. (Shehri 2012) Also, the Albanian readers could not be in touch with the recent development of Albanian literature written in Kosovo and Macedonia. They were also prohibited from reading books of traditional literature, because most writers of tradition were considered enemies of the state due to their European educational background. Moreover, the only books that were allowed to be translated into the Albanian language were books of realist and social-realist writers.

It is understandable that a literature without freedom could not follow its natural developmental track. However, even in those dark times of Albanian literature, there were some excellent examples of successful writers who challenged the strict rules of the system, hiding the message behind the lines like Ismail Kadare or, through activation of irony, Dritëro Agolli.

Albanian criticism suffered badly from the consequences of ideology. Dhimitër Shuteriqi, previously known as a realist writer, became the father of social realist criticism, a critical approach that considered ideology the core part of writing. $\mathrm{He}$ was also the main promoter of literature of social realism in Albania, which gave the final blow to critical thinking in communist Albania. (Miftari 2012: 254).

In these conditions where every new idea was censored, where each element of literary works was thoroughly monitored, where there were no other models of writing except the one that was accepted by Marxist criticism, Albanian literature was seriously impoverished. As a result, the reflection of the literature of this time in the literary periodicals was really insufficient; there were only a few writers (mostly the mediocre ones who were glorified and many others who were strongly attacked). This practice was used in order to prevent any possible deviation from the ideological line. This second period was defined by only one critical model, the Marxist one, and if the literary work did not meet the requirements of social realism it was simply banned from publishing and the consequences that the writers suffered were dramatic. 
There were a lot of periodicals in this period but literary journals were scarce. There was no room for the constructive debate, because of the unilateral and political approach to the literary phenomena. There were only two literary newspapers Drita (The Light) and Nëntori (November), which were considered the most important ones for the evaluation of the literary process. It was the darkest period in Albanian history and of course the darkest time for Albanian literature as well. Robert Elsie, a Canadian specialist on Albania, considers it an apocalyptic time for writers and publishers. Many of them died in prison or were executed. (Elsie 2007: 93)

Table 2. Periodicals published in $1945-1990$

\begin{tabular}{|l|l|l|l|}
\hline \multicolumn{1}{|c|}{$\begin{array}{c}\text { Year of } \\
\text { publication }\end{array}$} & \multicolumn{1}{|c|}{ Title } & \multicolumn{1}{|c|}{ Main Features } & \multicolumn{1}{c|}{ Place of publication } \\
\hline $1945-1947$ & Bota e re (New World) & $\begin{array}{l}\text { Cultural and } \\
\text { literary journal }\end{array}$ & Tiranë, Albania \\
\hline $1945-$ & $\begin{array}{l}\text { Zëri i popullit } \\
\text { (Voice of the People) }\end{array}$ & $\begin{array}{l}\text { Political, literary } \\
\text { journal }\end{array}$ & Tiranë, Albania \\
\hline $\begin{array}{l}1945-1993 \\
1995\end{array}$ & $\begin{array}{l}\text { Zëri } \text { R Rinisë (Voice of } \\
\text { Youth) }\end{array}$ & $\begin{array}{l}\text { Educational } \\
\text { journal }\end{array}$ & Tiranë, Albania \\
\hline $\begin{array}{l}1954-1992 \\
1992\end{array}$ & Nëntori (November) & $\begin{array}{l}\text { Artistic and } \\
\text { Literary journal }\end{array}$ & Tiranë, Albania \\
\hline $1961-1995$ & Drita (The Light) & Literary journal & Tiranë, Albania \\
\hline
\end{tabular}

As a result, this period produced mediocre literature and one-sided criticism. Every literary work that did not perfectly fit into the ideological template was criticized and immediate measures were taken with the writer. If a literary critic would not act quickly in order to stop the so-called foreign influence, immediate measures would be taken with him. The literary critic had to be alert in order to force the writers to follow the rules. Even though there were many journals and newspapers, only a few were published for literary purposes.

\section{1 - Present: Critical Writings and Online Periodicals}

After the 1990s, Albania literature was finally free from the Marxist approach, but on the other hand it was in a void left by the previous period. The critical studies had to take on new responsibilities. Albanian literature tried to find its natural pace of development. The process of evaluation suffered from chaos at first and then finally found the equilibrium of today. 
KËRBIZI, MACAJ

The post-1990 criticism faced other difficulties. The most important one was related to the lack of professional background of the new critics, who sometimes were unable to lead the readers toward genuine literary values.

Hence, the question raised was: How could critical studies recover from the lack of literary theories, literary models and literary interpretation that during the communist area were not properly acknowledged because of the prevalence of the Marxist ideology?

As a matter of fact, it is really important to clarify the status of Albanian critical studies (Shehri 2013) and newly estimate the values of Albanian literature, re-reading traditional Albanian literature with the aim of re-discovering the real interpretation detached from ideological interpretations that were usually found in the previous textbooks, or even in the previous critical studies.

A new window of information about literature and its evaluation process, totally free from pre-arranged schemes, was opened when the new periodicals appeared. They revived the literary climate, even though they often lacked financial support and as a result they had no long-term strategies to survive.

Even today, literary periodicals suffer from the lack of standardization or the implementation of international rules of blind peer-reviewing. They were mostly private initiatives of writers or even journalists who had a strong emotional connection to literature, where the writers were at the same time the editors and the publishers of the journals. Because every publication was supported by private initiative, sometimes the management and continuation of their publication in the conditions of the free market economy became a very difficult challenge. These conditions made Gentian Çoçoli (another writer and publisher) admit that publishing a literary journal today is akin to committing suicide. (Çoçoli 2012: 17). Taking into consideration even the online publication or online pages, the survival of literary or critical periodicals still remains a challenge.

However, it is important to say that after the 1990s in Albania or in other countries where the Albanian language is spoken, in region or diaspora, there is a sudden increase of literary journals. Another feature is related to a new context of communication between journals. These periodicals were mainly published in Tirana, but not only. ARS was published in Pristina and Skopje too. Journals now accept materials in English, German, Italian, French, Spanish and Greek as well. The good example here is POETEKA, a periodical closely related to literature and poetry. This periodical is among the few being published in Kosovo, Macedonia, Italy, Austria, France, Spain, Belgium, Croatia, Slovenia, Bosnia, Serbia, Great Britain, Bulgaria, Rumania, Greece, Russia, USA, Canada, etc.

Another very important characteristic of this period is the adaptation of the periodicals to new formats of writing. A great number of online literary journals have opened new paths in the evaluation of Albanian literature. 
Albanian Literature in Its Critical Evaluation Process.

To sum up, the main features of the literary periodicals were:

1. Albanian literature regained its inner natural pace through experimentation and new techniques, rising as a phoenix from the ashes.

2. Even literary criticism started a new process of revitalizing itself. However, sometimes it lacks professionalism due to the non-existent theoretical background inherited from the past.

3. Critical studies are often published in literary journals that are mostly financed by their own publishers, most of them being writers.

4. Along with the printed version of literary journals, there is a new trend of online journals that are developing fast but in an informal way.

5. The lack of statistical data makes it very difficult to estimate the impact these journals have had in the evaluation of Albanian literature.

Table 3. Periodicals published from 1990 to present

\begin{tabular}{|l|l|l|}
\hline Title & Main features & \multicolumn{1}{c|}{ Place of publication } \\
\hline Poeteka & Literary & Tiranë, Albania \\
\hline Kens & Critical & Tiranë (online) \\
\hline Perla (The Pearl) & Critical & Tiranë, Albania \\
\hline Palimpsest & Cultural and literary & Online \\
\hline Milosao & Literary supplement & Print-online \\
\hline Gegnia (Gegh) & Cultural & Shkodër, Albania \\
\hline Obelisk Memorial & Critical & Tiranë, Albania \\
\hline Ars & Literary & Tiranë, Albania \\
\hline Përpjekja (The Endeavour) & Critical & Tiranë, Albania \\
\hline Fjala (The Word) & Literary & Tiranë, Albania \\
\hline Aleph & Literary, critical & Tiranë, Albania \\
\hline Mehr Licht! & Literary, critical & Tiranë, Albania \\
\hline Saras & Literary & Tiranë, Albania \\
\hline Illz & Literary & Tiranë, Albania \\
\hline Aks & Literary supplement & Tiranë, Albania \\
\hline & &
\end{tabular}


KËRBIZI, MACAJ

\section{Conclusion}

Albanian literature and criticism have had their highs and lows. There have been three distinct periods. The first period, the 1920s to 1945, was coherent with the development of literature itself. Its critics were intellectuals who tried to create and evaluate at the same time. This period is characterized by the constructive nature of criticism and debate. The critical assessment of Albanian literature was reflected in a series of periodicals that have a certain periodization according to the typology of literature itself.

The second period, from 1945 to 1990, was characterized by social realism and Marxist criticism. The dictatorship would not allow literary creativity outside this scheme. As a result, the critics were very rigid and often biased. This period greatly damaged real literature, which was censored. In fact there was neither free literature nor criticism. The literature and criticism were oriented and instructed as to what to observe and how to politically educate the masses.

The years after 1990 have been a period of change and free movement. Initially criticism was chaotic until it found its balance. Faced with the influx of translations of models of world literature, Albanian literature began to move along with its critique. Critical articles in the periodicals of each period play a special role in identifying the process of evaluating Albanian literature in the country and abroad, although their professional status is not standardized. This evaluation process is as fragmentary as Albanian literature itself.

There are continuous attempt of communication among intellectuals and critics in discussions, conferences, seminars on Albanian literature and issues of its development. It is very important to underline that periodicals outside Albania also play a role in the evaluation process of literature. If communication with Kosovo has been ever-present, communication with other countries in the region has become more frequent in recent years. On the other hand, the Albanian-speaking areas add value to Albanian literature by continuing to publish periodicals in their respective countries. Also digital platforms now contribute to the literary process.

\section{Marisa Kërbizi}

marisakerbizi@yahoo.com

Alexander Moisiu University

ALBANIA

\section{Edlira Macaj}

edliralib@yahoo.com

Tirana University

ALBANIA 
Albanian Literature in Its Critical Evaluation Process.

\section{Bibliography}

Bobiciiĉ, N., Bozhoviq, Gj. 2012. Albanian literature in translation in Montenegro. Materialet e punimeve të Seminarit XXXI Ndërkombëtar për Gjuhën, Letërsinë dhe Kulturën Shqiptare. The $31^{\text {st }}$ International Seminar for Albanian Language, Literature and Culture. Prishtinë: UP\&UT, 197-200.

Coccheti, M. G. 2003. Revistat e reja letrare. - Ars, 28 shtator, 12.

Çoçoli, G. 2012. Sot është vetëvrasje letrare të botosh një revistë letrare. - Mapo. 483, 23 janar.

Dabishevci, D. 2012. Diskursiviteti për autorin-Konica sipas Arshi Pipës. - Materialet e punimeve të Seminarit XXXI Ndërkombëtar për Gjuhën, Letërsinë dhe Kulturën Shqiptare. The $31^{\text {st }}$ International Seminar for Albanian Language, Literature and Culture. Prishtinë: UP\&UT, 111-114.

Elsie, R. 2007. The national role of the Albanian Literary Journals. - M. Cornis-Pope, J. Neubauer, eds., History of Literary Cultures of East-Central Europe: Junctures and Disjunctures in the $19^{\text {th }}$ and $20^{\text {th }}$ Centuries, Vol. III: The making and remaking of literary institutions. Amsterdam/ Philadelphia: John Benjamins, 92-95.

Fevziu, B. 2005. Histori e shtypit shqiptar 1848-2005. Tiranë:Onufri.

Fjalori enciklopedik shqiptar. 2009. Tiranë: Akademia e Shkencave të Shqipërisë.

Hoxha, B. 2016. Revista letrare pa opinion. - https://www.gazeta-shqip.com/2016/04/06/ revista-letrare-pa-opinion/ (22.11.2020).

Kërbizi, M., \& Macaj, E. 2019. Negative Impact of Ideology in Albanian Literature. - Ö. Çakurtaș, ed., Language, Power, and Ideology in Political Writing: Emerging Research and Opportunities. Hershey, PA: IGI Global, 124-142. https://doi.org/10.4018/978-15225-9444-4.ch006

Kodra, K. 2012. Veçori të shkencës letrare të viteve të fundit. - Materialet e punimeve të Seminarit XXXI Ndërkombëtar për Gjuhën, Letërsinë dhe Kulturën Shqiptare. The $31^{\text {st }}$ International Seminar for Albanian Language, Literature and Culture. Prishtinë: UP\&UT, 243-247.

Koliqi, E. 2003. Vepra 1. Prishtinë: FAIK KONICA.

Kryeziu, R. 2009. Mendimi kritik letrar dhe historia e letërsisë. - Materialet e Konferencës shkencore, Historia e Letërsisë shqipe, 30-31 tetor 2009. Prishtinë: Akademia e Shkencave dhe e Arteve e Kosovës, Akademia e Shkencave e Shqipërisë, 209-214.

Kurowski, T. 2008. Some Notes on the History of the Literary Magazine. - Mississippi Review, 36(3), 231-243, http://www.jstor.org/stable/20132855 (22.11.2020).

Leka, A. 2012. Përballë njëra-tjetrës revistat letrare janë plotësuese. - Mapo, 483, 23 janar.

Meksi, M. 2011. Revista letrare - misioni i saj prej placente : eseja si pjesë e rëndësishme e revistës letrare. - Mehr Licht!, 40, mars, 5-11.

Miftari, V. 2012. Letërsia metatekstuale shqipe. -Materialet e punimeve të Seminarit XXXI Ndërkombëtar për Gjuhën, Letërsinë dhe Kulturën Shqiptare. The $31^{\text {st }}$ International Seminar for Albanian Language, Literature and Culture. Prishtinë: UP\&UT, 253-257.

Shala, K. 2012.Shekulli i kritikës shqipe. - Materialet e punimeve të Seminarit XXXI Ndërkombëtar për Gjuhën, Letërsinë dhe Kulturën Shqiptare. The $31^{\text {st }}$ International Seminar for Albanian Language, Literature and Culture. Prishtinë: UP\&UT. 
KËRBIZI, MACAJ

Shehri, Dh. 2012. Rilexime te letërsisë shqipe. - Materialet e punimeve të Seminarit XXXI Ndërkombëtar për Gjuhën, Letërsinë dhe Kulturën Shqiptare. The $31^{\text {st }}$ International Seminar for Albanian Language, Literature and Culture. Prishtinë: UP\&UT, 145-157. Shehri, Dh. 2013. Statusi i kritikës. Tiranë: Albas.

Tufa, A. 2012. Revistat letrare një specie në zhdukje. - Mapo, 483, 23 janar.

Vehbiu, A. 2019. Letërsia e sotme në rrjet. - Peizazhe të fjalës ose natyra jo aq të qeta, 25 qershor, https://peizazhe.com/2019/06/25/letersia-e-sotme-shqipe-ne-rrjet-i/ (22.11.2020).

Visoka, A.2012. Ndikimet e studimeve frënge në mëndimin letrar shqiptar. - Materialet e punimeve të Seminarit XXXI Ndërkombëtar për Gjuhën, Letërsinë dhe Kulturën Shqiptare. The $31^{\text {st }}$ International Seminar for Albanian Language, Literature and Culture. Prishtinë: UP\&UT, 13-25 August, 27-33. 